\title{
OSSIFICATION OF ENCYSTED TUMOURS.
}

\author{
By JOHN DALRYMPLE, EsQ., \\ SURGEON TO THE LONDON OPHTHALMIC HOSPITAI.
}

READ JUNE 13Th, 1843.

$\mathrm{ON}_{\mathrm{N}}$ the 28th of April I removed a small tumour from beneath the tarsal cartilage of the upper eyelid of a middle-aged man; which, instead of the usual cheesy matter, contained an apparently earthy or bony deposit. This tumour was somewhat larger than a pea, and composed of concentric layers of hard earthy material, and in form was rounded, except at the surface, immediately behind the conjunctiva, where it was somewhat flattened and rough. From its pressure it has caused absorption of the cartilage, and ulceration of the conjunctiva; hence the friction of its rough surface produced much pain, inflamed the conjunctiva scleroticæ, and rendered the upper part of the cornea opaque.

Upon examination by the microscope, the con- 
centric layers of this tumour were found composed entirely of epithelium scales closely agglutinated together: but instead of the usual transparent and thin lamina with its central nucleus, they were thickened and hard, and contained granular earthy molecules, which could be removed by immersion in weak muriatic acid. No amorphous earthy deposit existed around or among the scales, but the whole was composed of this epithelium, opaque, of a light brown colour, with a clear and large central nucleus.

The sebaceous or cheesy matter of encysted tumours, it is well known, consists of desquamated epithelium, somewhat disintegrated and mixed with oily globules; but here the mass may be said to have been ossified epithelium, or, in other words, these cells were filled with granular earthy deposit.

In structures ordinarily denominated ossified, it is probable, no true bone will be found to exist, except in those connected with original bony or cartilaginous tissues.

This case is interesting, in so far as I am unaware of any similar observation in regard to epithelium cells; and it adds one fact to our at present scanty information on the subject of cell secretion.

Mr. Bowman has recorded the great increase of oil globules in the cells of fatty liver; and Mr. Gulliver of biliary matter in the epithelial cells of the same organ affected with jaundice. But in both these instances the morbid condition consisted of an increase of what originally existed in a normal state, 
while in the present instance a totally new substance is found, in tissues where $a$ priori we should have been most unprepared to expect it.

Mr. Gulliver, who has confirmed these observations, informs me that the earthy material disseminated through the epithelium cells, is principally phosphate of lime, with a trace of carbonate of the same earth.

Fig. 1.-A represents a section of the tumour of its natural size, showing the concentric lamellæ.

B, a portion of one of the lamellæ, magnified about 450 diameters. The epithelial scales of which each layer is composed are

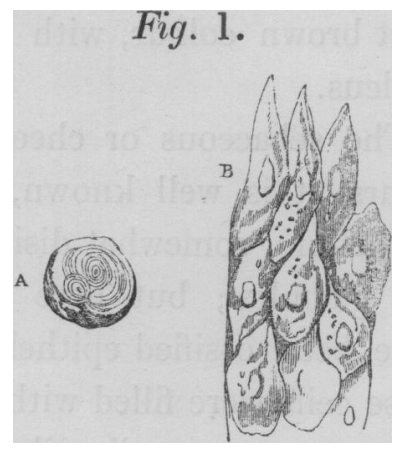
here distinctly seen; they are agglutinated to each other, and firmly adherent.

Fig. 2.-c, a single epithelium scale with its nucleus magnified 460 diameters. Instead, however, of the scale being flat and transparent, as in the ordinary state, it is thickened, slightly bi-convex, and contains granules of earthy deposit, phosphate, and a trace of carbonate of lime.

D, a cluster of epithelium scales, semi-trans- 
OSSIFICATION OF ENCYSTED TUMOURS. 241 parent, and showing thin nuclei, with here and there a nucleolus. These scales are irregular in shape, as they were obtained by pounding a portion of the laminæ, and diffusing the powder in water. 